\title{
TENAGA KERJA INDONESIA (TKI) DAN HUBUNGAN INDONESIA-MALAYSIA ERA JOKOWI
}

\author{
Ali Maksum \\ Jurusan Hubungan Internasional \\ Fakultas Ilmu Sosial dan Politik \\ Universitas Muhammadiyah Yogyakarta \\ Email: ali.maksum@fisipol.umy.ac.id
}

\begin{abstract}
Following the leadership succession in the post Presidential Election in 2014 from the 6th Indonesian President Susilo Bambang Yudhoyono to the 7th Indonesian President Joko Widodo (Jokowi), the Indonesian migrant workers became one of the priorities of the new government. The reason is simple, there are still many Indonesian workers especially in Malaysia who are involved in various problems and cases. The issue of protection of Indonesian citizens abroad became the primary agenda of Jokowi's administration including protection on migrant workers. To be sure, the various issues of migrant workers eventually impact on the relationship between the two brotherhod countries, Indonesia and Malaysia. On the other hand, both countries were obviously gained so many advantages from the influx of Indonesian migrant workers in Malaysia. For Indonesian government for instance, the migrant workers is one of the largest revenue contributors from their remittance. As for Malaysia, the presence of Indonesian migrant workers were highly contributed to the national economy amid of the local people are lack of interested to such kind of dirty jobs. Therefore, this article would like to invite readers into a deep discussion comprehensively on the issues of migrant workers and their implications on the Indonesia-Malaysia relations especially in the first half of Jokowi's tenure of presidency.
\end{abstract}

Keywords: Indonesian migrant workers, economic contributions, bilateral relations, Indonesia, Malaysia

\section{Pendahuluan}

\section{I.1 Tenaga Kerja Indonesia di Malaysia}

Membahas tentang tenaga kerja Indonesia (TKI) di Malaysia adalah sebuah hal yang sangat menarik. Karena, keberadaan TKI di Malaysia memberikan dampak signifikan bukan saja terhadap isu keuntungan ekonomi (remittance), namun juga menyangkut isu hubungan bilateral Indonesia-Malaysia. Pada awalnya proses migrasi atau lebih tepatnya kegiatan lintas- 
batas orang-orang Indonesia ke Malaysia lazim terjadi jauh sebelum kedua negara terbentuk (Yulyadi, 2009). Kedatangannya juga ditunggu-tunggu dan disambut dengan suka cita sebagai saudara serumpun tanpa melihat asal-usul karena masih dalam satu wilayah yang disebut Nusantara (Liow, 2005: 45). Pada mulanya, motivasi utama migrasi orang Indonesia ke Malaysia tidak lain adalah mencari penghidupan yang lebih baik. Namun, seiring dengan dinamika sosial-politik di Malaysia, pemerintah Kuala Lumpur ternyata melihat bahwa keberadaan orang-orang Indonesia di Malaysia bisa dimanfaatkan untuk memperkuat posisi politik orang Melayu khususnya Partai United Malays National Organization (UMNO) pasca kerusuhan antar etnis tahun 1969 (Liow, 2005: 46).

Persamaan budaya dan agama mayoritas yang dianut TKI, menjadi faktor penting mudahnya arus kedatangan pekerja Indonesia ke Malaysia. Selain itu, TKI dinilai lebih mahir dan pekerja keras dibanding pekerja dari negara lain (Nor Azizan Idris, 2005). Sayangnya, lambat laun seiring dengan meningkatnya jumlah TKI, sebagian besar TKI hanya mendominasi di tiga sektor utama yang dikenal dengan $3 D$ (dirty, dangerous and difficult) (Muhammad Iqbal \& Arifin Zainal, 2009). Bersamaan dengan meningkatnya jumlah TKI di Malaysia, berbagai masalah mulai muncul. Misalnya, semakin banyak TKI yang berstatus ilegal atau dalam istilah di Malaysia dikenal sebagai "pendatang haram" atau "pendatang asing tanpa izin (PATI).” Jumlahnya sangat mencengangkan. Kedutaan Besar Republik Indonesia (KBRI) di Kuala Lumpur, pada tahun 2012 saja memperkirakan jumlah warga Indonesia yang bekerja di Malaysia mencapai dua juta orang di mana setengahnya tinggal dan bekerja secara ilegal (Caraka, 2012).

Dalam konteks ini, wajar jika pemerintah Malaysia semakin khawatir dengan dampak yang ditimbulkan dari meningkatnya jumlah imigran terutama dari Indonesia. Hal ini tidak lain didasari oleh beberapa alasan yang mendesak untuk segera menangani pekerja Indonesia secara serius. Misalnya sebagian TKI ada yang terlibat kriminal dan mengganggu ketertiban masyarakat. Tahun 1987 saja, dari 36\% narapidana di penjara-penjara Malaysia adalah pendatang dari Indonesia (Liow, 2005: 148). Pada perkembangan berikutnya, TKI juga terlibat kerusuhan misalnya di sebuah penjara di Semenyih, negara bagian Selangor yang menyebabkan seorang polisi tewas dan sejumlah TKI cedera. Di rumah tahanan imigrasi Machap Umboo, negara bagian Melaka dan di penjara Pekan Nenas, Pontian, negara bagian Johor serta di Nilai, negara Negeri Sembilan. Kesemuanya melibatkan kontak fisik antara TKI dengan aparat keamanan Malaysia. Hasilnya, kerajaan Malaysia bereaksi keras dan mengancam akan memulangkan seluruh pekerja Indonesia. Sehingga lahir kebijakan yang dikenal dengan "Hire Indonesians Last” atau pekerja pilihan terakhir (Liow, 2005: 149-153).

Pada saat yang sama, kasus demi kasus yang menimpa TKI di Malaysia juga semakin meningkat. TKI sektor non-formal seperti pembantu rumah tangga adalah golongan yang paling rawan tertimpa berbagai kasus. Misalnya perkosaan, tempat tinggal yang tidak layak, eksploitasi dan lain sebagainya (Wan Abdul Rahman Wan Ab. Latif, 2012). Isu TKI di Malaysia juga semakin rumit dengan munculnya istilah "Indon" yang sangat familiar di Malaysia dalam setiap narasi melibatkan TKI (Nasrullah Ali Fauzi, 2009). Media di Malaysia juga tidak segan menyebut TKI sebagai "troublemaker" (Liow, 2004). Artinya, citra TKI di Malaysia juga semakin negatif dan seringkali kontribusinya tidak ditonjolkan. Sebaliknya, gambaran negatif tentang TKI selalu muncul di mata masyarakat Malaysia (Silfia Hanani, 2009). Namun kebijakan pemerintah Malaysia yang represif ternyata juga mendapat tantangan dari sebagian kelompok di Malaysia. Beberapa organisasi non-pemerintah (non-governmental organization, NGO) seperti Suara Rakyat Malaysia (SUARAM) dan Tenaganita mengkritik 
keras kerajaan Malaysia yang dinilai melanggar hak asasi manusia. NGO tesebut juga menuduh dan percaya bahwa terjadinya beberapa kerusuhan adalah akibat provokasi aparat keamanan terutama polisi (Liow, 2004).

Dampaknya tentu saja, isu TKI selalu memanaskan hubungan kedua negara akibat tindakan sebagian aparat dan masyarakat di Malaysia yang dinilai sewenang-wenang. Hal ini juga dilatarbelakangi oleh sikap sebagian warga Malaysia yang cenderung "merendahkan" warga Indonesia tidak terkecuali terlebih TKI. Di sisi lain, TKI dituntut untuk melengkapi segala keperluan dokumentasi agar tidak menjadi ilegal. Keberadaan TKI pada dasarnya juga tidak bisa dipandang dari sudut negatif saja. Bahkan TKI juga melakukan upaya-upaya menaikkan citra positif di mata masyarakat Malaysia. Banyak di antara TKI yang akhirnya berinisiatif mendirikan organisasi untuk mewadahi aspirasi dan melakukan kegiatan positif misalnya sosial-keagamaan hingga olahraga. Tampaknya, salah satu faktor penting mengapa mereka tergerak melakukan hal tersebut tidak lain adalah dampak dari reformasi tahun 1998 terkait kebebasan berorganisasi di Indonesia (Maksum \& Bustami, 2014). Bahkan dengan berbagai agenda positif tersebut secara tidak langsung juga memainkan peran sebagai jalur diplomasi kedua (second track diplomacy) yang sangat penting. Oleh karena itu, penelitian ini dianggap penting karena permasalahan TKI sangat kompleks dan berdampak langsung kepada hubungan bilateral Indonesia-Malaysia.

\section{I.2 Tenaga Kerja Indonesia Sebagai Fenomena Migrasi}

Salah satu konsekuensi logis dari globalisasi adalah terbentuknya sebuah tatanan dunia yang semakin kompleks. Sejak itulah muncul pula apa yang disebut dengan saling ketergantungan dalam bidang ekonomi. Konteks saling ketergantungan juga semakin meluas cakupannya hingga melibatkan aktor-aktor non-negara/transnasional. Sehingga, muncul istilah yang dikenal dengan "complex interdependence" (Keohane \& Nye, 2001: 20-32). Dalam analisis Keohane dan Nye, terjadinya "complex interdependence" disebabkan hubungan internasional semakin kompleks di mana tidak saja melibatkan hubungan antar negara, namun juga antar individu, antar organisasi transnasional serta pergerakan barang dan jasa yang semakin sulit dikendalikan. Hal ini terjadi karena adanya berbagai saluran interaksi atau dikenal dengan istilah multiple channels (Keohane \& Nye, 2001), sehingga siapa saja bisa melakukan kontak dengan mitranya di belahan dunia tanpa terkukung oleh sekat-sekat perbatasan. Abubakar Eby Hara (2009) menyatakan bahawa aktor non-negara seperti media massa, lembaga swadaya masyarakat (LSM) didukung oleh pesatnya perkembangan teknologi informasi (ICT) menjadikan dunia tanpa sekat dan tidak terbatas.

Migrasi merupakan contoh sederhana bagaimana pergerakan manusia lintas negara yang sangat sulit dikendalikan, apalagi di wilayah Malaysia-Indonesia. Menurut Lili Yulyadi Arnakim (2009) pergerakan manusia lintas perbatasan dari Indonesia ke Malaysia atau sebaliknya sudah ada sejak zaman kerajaan seperti Majapahit, Sriwijaya dan Melaka. Menurut Nor Azizan Idris (2005:148) persamaan budaya, agama serta bertipologi pekerja keras menjadi faktor penting massifnya gelombang migrasi terutama pekerja Indonesia ke Malaysia. Meningkatnya kebutuhan akan pekerja Indonesia bisa ditelusuri sejak tahun 1970-an dan 1980-an. Tetapi mayoritas bekerja di sektor perkebunan dan sebagian di sektor professional. Jumlah ini semakin meningkat setiap tahun hingga 57\% atau 12,277 pekerja pada tahun 1991 (Silfia Hanani, 2009). Menurut International Organization for Migration (IOM) migrasi 
Indonesia ke Malaysia termasuk yang terbesar kedua di dunia setelah migrasi MexicoAmerika Syarikat (International Organization for Migration, 2010).

Sementara, migrasi juga seringkali dikaitkan dengan isu keamanan baik yang terkait dengan masyarakat secara umum, maupun berhubungan dengan isu ancaman identitas negara, kesejahteraan sosial (Huysmans, 2006) dan isu kejahatan (AasFranko, 2007; Bigo, 2003; Pinyol-Jiménez, 2012). Tidak terkecuali fenomena kedatangan pendatang Indonesia pula menimbulkan permasalahan di Malaysia. Joseph Liow (2005: 148) misalnya mengungkapkan bahwa pada tahun 1987 saja 36\% dari keseluruhan jumlah narapidana di penjara-penjara Malaysia adalah pendatang Indonesia. Trend keterlibatan orang asing terutama dari Indonesia berbagai tindak kejahatan juga semakin meningkat pada tahun 1990-an. Pada tahun 1996 misalnya, muncul fakta bahwa imigran di Malaysia telah terlibat dengan berbagai tindak kejahatan dengan prosentase cukup tinggi yaitu $27.3 \%$ kasus pembunuhan, $18 \%$ percobaan pembunuhan, $35.6 \%$ perampokan kelompok bersenjata dan $16.3 \%$ perampokan bersenjata dilakukan oleh perorangan. Lebih mengejutkan lagi, dari jumlah tersebut, rata-rata 50\%-nya melibatkan pendatang Indonesia (Nor Azizan Idris, 2005: 152). Hal ini jelas akan mengganggu tidak saja kenyamanan TKI dalam bekerja, namun juga berimplikasi langsung dan tidak langsung kepada hubungan Indonesia-Malaysia secara umum.

\section{Pembahasan}

\section{II.1 Pendekatan Penelitian}

Artikel ini meruupakan hasil dari sebuah yang penelitian deskriptif dengan analisa kualitatif. Menurut Nasir (1998) penelitian deskriptif memuat deskripsi, gambaran atau lukisan secara sistematis, faktual dan akurat mengenai fakta-fakta, sifat- sifat serta hubungan antara fenomena yang diteliti. Sementara Supriyadi (2003) menjelaskan bahwa penelitian deskriptif adalah suatu penelitian yang terbatas mengungkapkan fakta. Hasil penelitian ditekankan pada pemberian gambaran secara obyektif tentang keadaan sebenarnya dari obyek yang dikehendaki.

Istilah penelitian kualitatif awalnya bersumber pada pengamatan kualitatif di mana sampel penelitian berdasar kepada purposive sampling dan bukan random sampling seperti dalam pendekatan kuantitatif. Dalam hal ini, penelitian kualitatif dapat didefinisikan sebagai tradisi tertentu dalam sebuah ilmu pengetahuan sosial. Penelitian kualitatif merupakan sebuah penelitian fundamental yang bergantung pada pengamatan manusia terhadap sebuah fenomena (Supriyadi, 2003). Oleh karena itu, penelitian akan menjawab permasalahan kajian yaitu:- (1) bagaimana terjadinya kasus-kasus yang melibatkan TKI di era pemerintah Joko Widodo?, (2) bagaimana implikasinya kasus-kasus tersebut kepada hubungan bilateral Indonesia-Malaysia?, dan (3) faktor-faktor apa saja yang mempengaruhi sikap politik luar negeri Indonesia terkait TKI di Malaysia?

\section{II.2 Metode Pengumpulan Data}

Penelitian ini dijalankan melalui penelitian perpustakaan (library research) dan menggunakan analisis dokumen. Secara spesifik sumber data kajian ini adalah:- i) dokumen resmi yang tersedia misalnya publikasi resmi, laporan tahunan, dan kertas putih (white papers) dari lembaga/kementerian terkait; dan ii) informasi terkait yang diterbitkan dalam berbagai bentuk misalnya laporan resmi (official statement), konferensi pers, dan laporan media/komentar/debat/wawancara melalui surat kabar, majalah dan dalam internet. Berbagai 
sumber data tersebut umumnya diperoleh melalui internet. Penelitian ini juga dilengkapi dengan data lapangan melalui wawancara terstruktur (structured interview) dan diskusi kelompok terarah (focus group discussion, FGD). Peneliti akan melakukan wawancara dengan pihak-pihak yang mempunyai pengetahuan tentang politik luar negeri Indonesia khususnya terkait isu TKI di Malaysia misalnya pakar, dosen, peneliti dan pengamat politik. Untuk mengakses narasumber tersebut penulis merancang berbagai strategi pengumpulan data misalnya bertemu langsung, melalui kenalan peribadi termasuk melalui korespondensi surat elektronik (e-mail).

\section{II.3 Metode Analisis Data}

Dalam penelitian ini penulis menggunakan pendekatan analisis dokumen untuk menganalisis data. Analisis dilakukan dengan menganalisis secara sistematis isi data-data yang menjadi sumber utama kajian ini. Analisis dilaksanakan untuk memberikan pandangan baru, meningkat kepahaman peneliti terkait fenomena tertentu atau menjelaskan suatu tindakan. Selain itu, pendekatan ini memerlukan bacaan yang mendalam terhadap suatu teks. Dengan pendekatan ini, peneliti bisa melakukan interpretasi terhadap teks (analitis mahupun kritis) narasi yang sudah diterima dalam dunia akademis (White \& Marsh, 2006).

Dalam penelitian ini, analisis framing dilakukan denngan mengidentifikasi suatu kasus/isu tertentu, menguji dan membandingkan dengan berbagai sumber data terutama media yang menjadi fokus penelitian (Chong \& Druckman, 2007: 106). Dengan membandingkan isuisu tertentu antar media masa termasuk media sosial sebagai media alternatif akan diperoleh gambaran dan tipologi isu/kasus yang menjadi fokus penelitian.

Penelitian kualitatif berjalan serentak mulai dari pengumpulan data, analisis data dan interpretasi data. Karena sifat data penelitian kualitatif sendiri bersifat subjektif, interpretatif, deskriptif, menyeluruh dan banyak jumlahnya. Temuan penelitian disajikan dalam bentuk kutipan (Ahmad Naqiyuddin Bakar, 2008) atau diskripsi sementara sebagian data termasuk data statistik yang diperoleh dari sumber resmi (Ruenwai, 2006). Adapun data dapat disajikan melalui kutipan kunci, tabel, matriks, bagan atau model. Selain itu, bisa juga menggunakan kutipan langsung (direct quotes), pernyataan/cerita atau kutipan dari wawancara, FGD, catatan lapangan atau data-data utama adalah metode yang biasa digunapakan dalam penelitian kualitatif. Namun, pada dasarnya presentasi dari analisis data dalam penelitian kualitatif bersifat fleksibel (Cohen \& Crabtree, 2006).

\section{II.4 Skenario dan Kompleksitas Isu TKI di Awal Pemerintahan Jokowi}

Membincangkan isu TKI dan hubungan Indonesia-Malaysia era Presiden Jokowi, maka perlu dibahas beberapa aspek yang sangat berkaitan satu sama lain. Setidaknya ada tiga elemen yang perlu dijabarkan yaitu kebijakan pemerintah Jokowi terkait TKI khususnya di Malaysia, beberapa kasus yang melibatkan TKI di Malaysia dan implikasinya terhadap dinamika hubungan Indonesia-Malaysia.

\section{II.5 Gambaran Umum Kebijakan Presiden Jokowi Terkait TKI di Malaysia}

Secara umum kondisi dan dinamika permasalahan TKI di Malaysia tampaknya tidak berubah. Hal ini bisa dilihat dari berbagai kasus yang melibatkan TKI masih terus terjadi 
terutamanya kasus penganiayaan terhadap pembantu rumah tangga asal Indonesia. Artinya bahwa dinamika TKI di Malaysia era pemerintahan Jokowi masih menjadi isu klasik yang mau tidak mau akan menjadi sorotan masyarakat. Secara tidak langsung juga isu TKI juga akan berdampak pada dinamika hubungan Indonesia dengan negara jiran Malaysia.

Ketika masa kampanye Pemilihan Presiden 2014, calon Presiden Jokowi melontarkan beberapa isu terkait dengan TKI secara umum terutama masalah perlindungan warga negara Indonesia (WNI). Dalam Visi-Misinya, pasangan Jokowi-Jusuf Kalla dinilai lebih komprehensif dalam menanggapi isu TKI termasuk di Malaysia. Tidak heran salah satu NGO yang peduli dengan masalah-masalah buruh migran yaitu Migrant Care sangat mengapresiasi gagasan Capres Jokowi-JK. Menurut Migrant Care dalam sebuah Siaran Persnya menyatakan bahwa:-

"Dengan pembacaan kritis terhadap visi-misi mengenai perlindungan buruh migran Indonesia, harus diakui bahwa agenda perlindungan buruh migran yang diajukan oleh pasangan Joko Widodo-Jusuf Kalla lebih komprehensif dibandingkan pasangan Prabowo Subianto - Hatta Rajasa” (Migrant Care, 2014).

Hal jelas apa yang diutarakan Migrant Care menunjukkan apresiasi yang tinggi kepada Presiden Jokowi bahkan sejak awal masa kampanye. Sedangkan dalam menilai pasangan lain yaitu Prabowo Subianto-Hatta Rajasa, Migrant Care menilai bahwa:-

"Prabowo Subianto mulai nimbrung pada bulan September 2013 (terkait kasus yang menimpa TKI Wilfrida di Malaysia). Jadi bisa dikatakan, keterlibatan Prabowo Subianto di tikungan terakhir saja" (Berita Satu, 23 Juni 2014).

Faktanya, kebijakan Presiden Jokowi berkebalikan dengan visi-misi kampanye yang berkomitmen memperjuangkan kehidupan TKI. Migrant Care yang sangat mengapresiasi visimisi Jokowi berbalik arah karena merasa kecewa dengan rencana penghentian program pengiriman TKI ke luar negeri pada tahun 2017. Bukti keseriusan pemerintah untuk menghentikan program pengiriman TKI ke luar negeri khususnya sektor pembantu rumah tangga sebagaimana penegasan Menteri Ketenagakerjaan, Hanif Dhakiri bahwa:-

"Pada tahun 2017, diharapkan Indonesia tidak lagi mengirimkan tenaga kerja sektor informal atau pembantu rumah tangga ke luar negeri" (VOA Indonesia, 25 Februari 2015). tersebut:-

Tentu saja Migrant Care bereaksi keras dengan mengatakan bahwa kebijakan

"sangat bertentangan dengan janji kampanye Presiden Joko Widodo dalam kampanyenya [...] penghentian pengiriman TKI informal ke luar negeri sangat diskriminatif (VOA Indonesia, 25 Februari 2015).

Sikap pemerintah Jokowi jelas menimbulkan semacam ketidakpuasan di kalangan TKI yang berharap masih bisa bekerja di luar negeri sebagai TKI. Tidak dipungkiri bahwa kebijakan tersebut hanya sebatas retorika belaka mengingat negara jelas belum siap menerima segala konsekuensi dari penghentian pengiriman TKI tersebut. Jika kebijakan penghentian TKI benar-benar diimplementasikan, maka yang menjadi pertanyaan pertama adalah terkait dengan nasib para TKI tersebut di tengah terbatasnya lowongan pekerjaan. Negara juga dilihat 
tidak memiliki upaya kongkrit serta terobosan dalam rangka pemembukaan lapangan pekerjaan secara massif agar masyarakat tidak perlu pergi jauh ke luar negeri untuk menafkahi diri dan keluarganya.

Terkait dengan isu penghentian pengiriman TKI, para "pahlawan devisa" menanggapinya beragam. Salah seorang tokoh TKI di Malaysia mengatakan bahwa jika rencana pemerintah tersebut dilaksanakan maka:

"Jika kebijakan ini rasional kita dukung...tapi jangan marah nyamuk kelambu dibakar" (Khairudin Harahap, 6 Mei 2015).

Pernyataan di atas menunjukkan sebuah harapan sekaligus "peringatan" kepada pemerintah terkait rencana kebijakan penghentian pengiriman TKI. Peringatan tersebut bisa diartikan bahwa para TKI sebenarnya sadar dengan segala keterbatasan dan kondisi bekerja di luar negeri, kebijakan tersebut masih menyisakan banyak tanda tanya terutama nasib mereka pasca penghentian. Karena mereka juga sadar bahwa nasib dan hasil yang didapatkan selama ini di luar negeri mungkin masih lebih baik dibanding rekan-rekan mereka di tanah air. Belum lagi, rata-rata juga tahu betul bahwa pemerintah belum bisa menyediakan lapangan pekerjaan secara layak. Artinya, mereka pesimis dengan kebijakan penghentian pengiriman TKI ke luar negeri. Rasa pesimisme tersebut sebagaimana diungkapkan oleh salah satu TKI dalam narasi berikut:-

"Bagaimana bisa bekerja di negeri sendiri? Aku hanyalah lulusan SMK? Sedangkan di Indonesia sarjana saja banyak yang menganggur” (Pipiet Senja, 2015: 37).

Dalam kesempatan yang lain, seorang TKI yang sudah cukup lama tinggal dan bekerja di Malaysia mengatakan bahwa rencana pemerintah menghentikan pengiriman TKI terkesan mendadak dan tidak melalui kajian mendalam. Hal ini disebabkan permasalahan TKI yang cukup kompleks dan tidak bisa diselesaikan hanya dengan menghentikan pengiriman. Perlu banyak strategi dan langkah sebelum melakukan penghentian pengiriman TKI, misalnya terkait kesiapan lapangan pekerjaan serta solusi bagi mereka yang akan kembali ke tanah air dengan kehidupan baru dan dimulai dari titik nol. Dalam sebuah wawancara dengan seorang TKI yang sudah cukup "mapan" di Malaysia menyatakan:-

"Langkah pemerintah tersebut justru menunjukkan kelemahan pemerintah sendiri yang tidak bisa mengatasi berbagai masalah dengan baik termasuk terkait isu TKI di luar negeri" (Wawancara, 13 Juni 2017).

Pernyataan di atas jelas menunjukkan bahwa meskipun berbagai upaya sudah dilakukan untuk meyakinkan bahwa ada solusi untuk membuka lapangan pekerjaan, namun realitas di lapangan memang masih belum bisa dirasakan secara nyata. Fakta bahwa para pemuda-pemudi Indonesia sangat sulit mencapi pekerjaan adalah sebuah masalah yang harus segera dicarikan jalan keluar. Artinya, sampai hari ini bekerja menjadi TKI di luar negeri masih menjadi sebuah solusi sebagian masyarakat Indonesia. Apalagi mereka yang sudah menjalani profesi tersebut bertahun-tahun lamanya (Wawancara, 13 Juni 2017). Oleh karena itu, munculnya berbagai masalah juga tidak lepas dari banyaknya jumlah TKI yang berada di luar negeri ditambah dengan peliknya proses mulai pra-keberangkatan hingga tiba di tanah air. Faktanya, masih banyak aparatur dan pihak-pihak yang tidak bertanggungjawab memanfaatkan "kelemahan" TKI demi mencari keuntungan sesaat. Sehingga tidak mengherankan hal ini memicu massifnya perdagangan manusia dengan berbagi cara dan strategi (Syamsuddin and Azlinda Azman, 2015). 
Sementara dari sisi regulasi pemerintah Jokowi masih merujuk kepada UndangUndang (UU) Nomor 6 Tahun 20111 tentang Keimigrasian. Selain itu pemerintah Jokowi juga berinisiatif untuk melakukan revisi Undang-Undang (UU) Nomor 39 Tahun 2004 tentang Penempatan dan Perlindungan Tenaga Kerja Indonesia di Luar Negeri (PPILN). Terkait dengan revisi ini, orientasi pemerintah masih bersifat birokatif dengan berencana membentuk Atase Ketenagakerjaan untuk melindungi TKI di sebuah negara tujuan (Kompas.com, 20 Maret 2017). Sampai saat ini proses revisi juga masih dalam proses dan belum jelas arahnya (Kompas.com, 20 Maret 2017). Namun banyak TKI juga mengapresiasi kinerja Jokowi yang menghapus peraturan yang selama ini menyulitkan TKI yaitu perlunya memiliki Kartu Tenaga Kerja Luar Negeri (KTKLN) (BBC Indonesia, 30 November 2014). Meskipun demikian, pasca penghapusan KTKLN nasib TKI tetap tidak berubah. Para TKI masih diperas dan diperlakukan buruk oleh aparat negara meskipun sudah memiliki KTKLN sebagaimana narasi berikut:-

"Petugas Pos Pelayanan Penempatan dan Perlindungan Tenaga Kerja Indonesia (P4TKI) Dumai mencegah tangkal dan menolak Buruh Migran Indonesia di Pelabuhan Dumai hanya karena tak memiliki KTKLN. Buruh migran yang dicekal adalah Kaspul Anwar (No. Paspor AR708169) dan istrinya Fisa Liza (No. Paspor AR267462). Dua Petugas P4TKI di pelabuhan Dumai justru arahkan Liza dan Anwar untuk temui calo dan membayar Rp 300.000/orang. Anwar dan Liza adalah TKI yang cuti karena anaknya sakit" (Pusat Sumber Daya Buruh Migran, 2 Desember 2014).

Hal di atas menunjukkan bahwa apa yang sudah menjadi kebijakan pemerintah Jokowi dalam tataran praktek di lapangan masih belum maksimal. Meskipun pemerintah pusat sudah menginstruksikan aturan-aturan yang meringankan TKI, namun masih banyak aparat pemerintah yang lalai atau sengaja melanggar peraturan sehingga justru TKI kembali menjadi korban. Dengan segala keterbatasan yang dimiliki TKI, masih besar kemungkinan TKI akan terus-menerus menjadi korban aparat yang tidak bertanggungjawab. Budaya korupsi tampaknya masih sulit untuk dihilangkan meskipun pemerintah sendiri sudah membentuk apa yang disebut sebagai Sapu Bersih Pungutan Liar (Saber Pungli). Artinya ada indikasi kinerja Saber Pungli masih belum maksimal disebabkan para aparat yang "di dalam" masih belum "benar-benar bersih" dan oleh karenanya harus "dibersihkan" dulu (Okezone, 16 Januari 2017).

Dengan demikian, kebijakan pemerintah terkait TKI tidak jauh berbeda dengan pemerintahan sebelumnya. Di tengah berbagai kasus yang menimpa TKI di Malaysia, pemerintah Susilo Bambang Yudhoyono juga dinilai masih gagal dalam menangani isu TKI terutama terkait masalah perlindungan dan maraknya kasus penganiayaan terhadap pembantu rumah tangga asal Indonesia (Migrant Care, 2009). Sementara, di periode awal pemerintahan Presiden Jokowi atau akhir 2014, perkembangan isu TKI terutama terkait jumlah TKI yang dikirim ke Malaysia bisa dikategorikan masih tinggi meskipun mengalami penurunan. Badan Nasional Penempatan dan Perlindungan Tenaga Kerja Indonesia (BNP2TKI) mencatat adanya penurunan jumlah TKI yang dikirim ke luar negeri. Menurut cacatan BNP2TKI, jumlah TKI yang dikirim ke luar negeri tahun 2014 mencapai 429.872 orang dengan berbagai negara tujuan. Jumlah tersebut terdiri dari 219.610 orang (58\%) bekerja di sektor formal dan 182.262 orang $(42 \%)$ ditempatkan di sektor informal terutama pembantu rumah tangga. Dalam laporan BNP2TKI juga terungkap bahwa Provinsi Jawa Barat menempati urutan pertama penyumbang TKI sebanyak 105,479 disusul Jawa Tengah 92.590, Jawa Timur 78.306, Nusa Tenggara Barat 61.139 serta provinsi lain, namun dengan jumlah di bawah lima puluh ribu orang. Menariknya 
kabupaten penyumbang TKI terbesar bukan dari Jawa Barat namun Lombok Timur dengan total TKI sebanyak 29.510 orang. Sedangkan Malaysia adalah negara penerima jasa TKI terbesar tahun 2014 dengan total 127.827 orang disusul Taiwan 82.665, Arab Saudi 44.325, Hong Kong 35.050, Singapura 31.680, Oman 19.141 dan lain-lain (Situs Resmi BNP2TKI, 16 Januari 2015).

\section{II.6 Beberapa Kasus TKI di Malaysia Era Jokowi}

Selama paruh pertama periode kepemimpinan Presiden Jokowi, berbagai kasus yang melibatkan TKI masih terjadi. Misalnya satu bulan sebelum dilantik, tepatnya September 2014, masyarakat dikejutkan dengan sebuah kasus penganiayaan TKI. Kali ini menimpa tiga warga negara Indonesia asal Sukabumi tepatnya Kecamatan Parungkuda. Ketiganya disekap oleh majikannya di sebuah perusahaan pembuatan mie di negara bagian Sarawak, Malaysia. Diduga kuat ketiga warga negara Indonesia tersebut adalah korban perdagangan manusia dan perbudakan oknum-oknum yang tidak bertanggung jawab. Kasus ini teruangkap ke publik setelah salah satu korban berhasil melakukan kontak dengan keluarganya di Sukabumi. Kemudian, pihak keluarga melaporkan kejadian tersebut ke Pusat Pelayanan Terpadu Pemberdayaan Perempuan dan Anak (P2TP2A) Kabupaten Sukabumi yang selanjutnya pihak P2TP2A meneruskan ke pihak yang berwenang khususnya Kementerian Ketenagakerjaan (Koran Sindo, 5 September 2014).

Kasus seterusnya yang melibatkan TKI adalah kasus penganiayaan yang menimpa Meriance Kabu, TKI asal Kupang, Nusa Tenggara Timur (NTT) pada bulan Desember 2014. Meriance Kabu mendapat perlakuan yang sangat tidak manusiawi oleh majikannya di sebuah apartemen di Ampang, Kuala Lumpur, Malaysia. Meriance misalnya mengaku disiksa dengan berbagai cara seperti meminum air urine sendiri, dicabut giginya ketika pingsan termasuk mengalami kekerasan di bagian alat vitalnya. Kasus tersebut sudah ditangani oleh pihak KBRI di Kuala Lumpur dan aparat setempat. Akibat adanya kasus penganiayaan Meriance desakan kepada pemerintah untuk menghentikan pengiriman TKI khususnya sektor pembantu rumah tangga segera dihentikan yang memang sudah menjadi agenda pemerintah Jokowi. Pasca kasus penganiayaan tersebut Meriance berpesan kepada masyarakat Indonesia khususnya warga NTT untuk bekerja di kampung halaman sendiri saja meskipun dengan hasil yang tidak maksimal daripada bekerja di Malaysia tetapi mendapatkan musibah (Liputan 6, 24 Desember 2014; Kompas.com, 25 Desember 2014).

Memasuki tahun 2015, kasus penganiayaan TKI di Malaysia terus terjadi. Kali ini melibatkan Norfia Linda, TKI asal Lombok Timur, Nusa Tenggara Barat (NTB) yang disiksa majikannya di negara bagian Selangor Malaysia pada bulan April 2015. Kasus tersebut sudah ditangani oleh KBRI dan aparat berwenang setempat. Dalam pengakuannya Norfia mendapatkan perlakuan sangat menyedihkan misalnya dipukul dengan rotan dan tongkat besi. Akibatnya bagian tubuhnya mengalami luka serius terutama muka, kepala, punggung, serta satu jari tangan patah akibat penyiksaan tersebut sebelum akhirnya secara tragis dibuang di sebuah perkampungan orang asli di pinggiran hutan oleh majikannya. Adanya kasus tersebut telah memicu aksi demonstrasi di depan Istana Merdeka Jakarta oleh kelompok yang menamakan sebagai Aliansi TKI (Detik, 23 April 2015).

Tahun 2015, cerita tentang kisah sedih TKI ditutup dengan kasus penganiayaan yang menimpa Nurjanah binti Saidi, TKI asal Kabupaten Sambas, Provinsi Kalimantan Barat pada bulan Desember 2015. Nurjanah disiksa majikannya di Miri, negara bagian Sarawak, Malaysia 
hingga mengalami luka serius di bagian mata dan giginya patah. Lebih menyedihkan lagi, Nurjanah tidak pernah menerima gaji selama dua tahun bekerja dengan majikannya tersebut. Kasus Nurjanah langsung ditangani oleh Konsulat Jenderal Republik Indonesia (KJRI) Kuching, Balai Pelayanan Penempatan dan Perlindungan TKI (BP3TKI) Pontianak, dan Polis Diraja Malaysia (PDRM). Majikan Nurjanah juga langsung ditangkap kepolisian Malaysia (Liputan 6, 31 Desember 2015).

Setelah melewati tahun 2015, berita tentang penganiayaan TKI kembali terulang tahun 2016. Pada bulan Februari 2016, sebuah video berdurasi pendek terkait penganiayaan TKI menjadi viral di media sosial di Indonesia. Video tersebut mendemonstrasikan aksi penganiayaan TKI dengan cara dipukul menggunakan semacam cambuk sesekali ditambahi dengan tendangan ke bagian tubuh korban. Ada dugaan, korban dituduh mencuri harta milik perusahaan di mana TKI bekerja. Meskipun belum teridentifikasi siapa yang pelaku dan korban, setidaknya kasus tersebut bisa menjadi gambaran bahwa kasus penganiayaan terhadap TKI masih saja terjadi dengan skenario yang hampir sama yaitu kekerasan fisik (Tribun Medan, 22 Februari 2016).

Tahun 2016, ditutup dengan sebuah kasus yang sangat menggemparkan masyarakat Indonesia. Adalah kasus penganiayaan sadis yang dialami oleh Suyanti Binti Sutrisno, TKI asal Kota Medan, Sumatera Utara pada bulan Desember 2016. Suyanti yang baru bekerja dua minggu bekerja di Malaysia sebagai pembantu rumah tangga di Kuala Lumpur. Suyanti terpaksa melarikan diri dari majikannya setelah mengalami berbagai penganiayaan dan lukaluka di sekujur tubuhnya termasuk fasilitas makan dan mandi sehari sekali serta memutus semua sarana komunikasi dengan dunia luar. Setelah dengan segala cara lari dari majikan, Suyanti diselamatkan oleh warga lokal beretnis Melayu di sebuah selokan dalam keadaan luka-luka dan dibawa ke kantor polisi terdekat. Pihak KBRI juga langsung memberikan advokasi dan bantuan termasuk melayangkan protes keras kepada pemerintah Malaysia terkait dengan kasus tersebut. Kepolisian Malaysia langsung menangkap pelaku penganiayaan tidak lama setelah kasus Suyanti terkuak ke publik. Kasus Suyanti juga menjadi pemberitaan utama di media-media lokal Malaysia (Kini News, 24 Desember 2016; Okezone, 24 Desember 2016; Detik, 27 Desember 2016; Situs Resmi BNP2TKI, 27 Desember 2016).

Sementara awal tahun 2017, tepatnya awal bulan Februari masyarakat dikejutkan dengan kasus Siti Aisyah, TKI asal Kabupaten Serang, Banten yang terlibat pembunuhan tokoh politik Korea Utara, Kim Jong-nam, di Malaysia. Kasus tersebut menyita perhatian tidak hanya di Indonesia, tetapi juga publik internasional karena melibatkan tokoh politik Korea Utara. Bahkan akibat adanya kasus pembunuhan tersebut, hubungan Malaysia-Korea Utara memanas ditandai dengan saling melakukan pencekalan dan perintah penangkapan diplomat oleh kedua negara. Hubungan kedua negara kembali normal pasca kesepakatan kedua pihak terkait pemulangan jenazah Kim Jong-nam (BBC, 7 April 2017). Sementara, Siti Aisyah langsung diamankan oleh kepolisian Malaysia setelah melakukan penyelidikan atas kamera CCTV Bandara Internasional Kuala Lumpur. Siti Aisyah "diduga" dijebak oleh intelijen untuk melakukan pembunuhan tokoh Korea Utara dalam skenario "reality show." Sebagai imbalannya Aisyah dijanjikan akan menerima upah sebesar 400 Ringgit Malaysia (1,2 juta Rupiah) (Utusan Malaysia, 17 Februari 2017). Bagaimanapun, Siti Aisyah telah menjalani beberapa kali persidangan dan terancam dengan pasal 302 (Seksyen 302) Hukum Pidana (Kanun Keseksaan) Malaysia dengan ancaman hukuman mati jika terbukti bersalah (Utusan Malaysia, 8 Juni 2017). 
Masih pada bulan yang sama, publik juga dikejutkan dengan kasus kematian Jubaedah seorang TKI asal Cirebon, Jawa Barat yang meninggal secara mengenaskan setelah dianiaya majikannya sendiri. Sebelumnya, Jubaedah diduga meninggal karena jatuh atau terpeleset dari rumah majikannya. Namun, hasil penyelidikan pihak kepolisian dan rumah sakit di George Town Penang, menunjukkan bahwa TKI tersebut merupakan korban pembunuhan yang tidak lain dilakukan oleh majikannya sendiri. Kasus Jubaedah sudah ditangani pihak yang berwenang dan pelakunya yaitu pasangan suami-istri telah ditangkap kepolisian Malaysia (Okezone, 27 Februari 2017; Okezone, 1 Maret 2017).

Dengan demikian, selama paruh pertama pemerintahan Presiden Jokowi, kasus demi kasus yang melibatkan TKI di Malaysia masih terus terjadi. Dalam hal ini pemerintah jelas sudah melakukan berbagai upaya untuk membantu korban dan menyelesaikannya di jalur hukum di Malaysia termasuk melayangkan protes kepada pemerintah Malaysia. Namun berbagai kasus di atas juga menunjukkan bahwa permasalahan TKI masih menjadi pekerjaan rumah pemerintah yang tidak mudah untuk diselesaikan dalam waktu singkat. Masalah bangsa yang multi-dimensi menjadi hambatan sekaligus tantangan pemerintah untuk dicarikan solusinya demi kesejahteraan semua lapisan masyarakat tidak terkecuali para TKI di Malaysia.

\section{II.7 Implikasi kepada Hubungan Indonesia-Malaysia}

Adanya berbagai kasus di atas jelas pada akhirnya berdampak pada hubungan Indonesia-Malaysia secara umum terutama era pemerintahan Presiden Jokowi. Dinamika hubungan kedua negara dalam beberapa kasus dan periode sebelumnya pada dasarnya tidak ada perubahan signifikan. Malaysia misalnya, dalam menyikapi TKI terkesan bersikap ambivalent. Alasannya sederhana, yaitu pemerintah Malaysia masih membutuhkan jasa TKI yang bisa dikatakan masih memiliki tarif upah rendah terutama sektor pertanian dan konstruksi dibanding negara lain. Sedangkan warga negara Malaysia atau masyarakat lokal jelas tidak ada yang mau bekerja di sektor yang dikenal dengan $3 D$ (dirty, dangerous, and difficult) (Muhammad Iqbal dan Arifin Zainal, 2009). Namun pada waktu yang sama, Malaysia juga tidak ingin terdampak oleh membanjirnya TKI yang berpotensi bisa menganggu ketertiban masyarakat, sosial dan bahkan keamanan negara jiran (Nor Azizan Idris, 2009). Bagi Indonesia, tentu dengan banyaknya TKI di Malaysia secara tidak langsung diuntungkan karena bisa mengurangi angka pengangguran yang sangat tinggi di tengah terbatasnya lowongan pekerjaan (Wan Shawaluddin Wan Hassan dan Zaini Othman, 2009).

Dalam konteks pemerintahan Presiden Jokowi ada beberapa hal yang bisa dibincangkan untuk dijadikan analisa terkait TKI dan implikasinya kepada hubungan Indonesia-Malaysia. Misalnya, terkait dengan maraknya kasus penganiayaan TKI di Malaysia pemerintah mewacanakan sistem satu pintu. Hal ini merupakan hasil kesepakatan bersama antara Presiden Jokowi dan Perdana Menteri Najib Razak dalam kunjungan perdananya ke Malaysia pasca dilantik menjadi Presiden Indonesia ke-7. Kesepakatan tersebut lahir dari permasalahan mendasar yang selam ini menjadi akar munculnya berbagai kasus yaitu rumitnya masalah agen TKI (PJTKI). Selama ini agen TKI bebas merajalela melakukan operasinya yang mengakibatkan timbulnya masalah termasuk memicu adanya kasus perdagangan manusia dan menjamurnya TKI ilegal. Pasca pertemuan Jokowi-Razak, kedua negara sepakat untuk merampingkan serta memberantas agen-agen TKI nakal baik di Indonesia maupun di Malaysia. Kedua negara sepakat untuk menggunakan jalur government to government dalam proses perekrutan TKI. Selain kesepakatan satu pintu, kedua negara 
setuju untuk membentuk Join Working Group (JWG) untuk menangani masalah TKI (Sinar Harapan, 17 Maret 2015).

Hubungan kedua negara dalam kasus TKI sedikit terganggu dengan keterlibatan Ajeng Yulia, salah seorang TKI asal Jakarta dalam kasus narkotika. Kasus Ajeng mencuat ke publik pasca putusan pengadilan Malaysia yang memvonis hukuman mati karena didakwa menyelundupkan narkoba jenis methapethamine. Menteri Ketenagakerjaan juga memastikan bahwa pemerintah sekuat tenaga akan membantu dan mengadvokasi kasus Ajeng Yulia. Namun, hukuman mati sudah terlanjur diputuskan oleh pengadilan Malaysia. Ajeng mengaku hanya sebagai "korban" konspirasi bandar narkoba yang melibatkan warga negara Nigeria bernama Stanley hasil perkenalannya di media sosial. Bagaimanapun Ajeng Yulia gagal membuktikan di pengadilan bahwa dirinya tidak bersalah dalam kasus tersebut (Sinar Harapan, 28 Februari 2015; Sinar Harapan, 4 Maret 2015). Pemerintah Malaysia melalui Menteri Dalam Negeri Datuk Seri Ahmad Zahid Hamidi menyatakan bahwa peredaran narkoba di negeri jiran tersebut sudah sangat mengkhawatirkan karena banyaknya korban terutama generasi muda (Merdeka.com, 2 Maret 2015).

Isu lain yang melibatkan hubungan kedua negara terkait masalah TKI adalah langkah deportasi pemerintah Malaysia dalam beberapa tahun terakhir. Di awal pemerintahan Jokowi, pemerintah Malaysia sudah berencana akan mendeportasi sekitar 50.000 TKI ilegal. Berdasarkan catatan KBRI Kuala Lumpur angka tersebut tersebar di beberapa negara bagian dengan berbagai kasus dan masalah. Misalnya di Johor ada sekitar 21.000 TKI ilegal dan di negara bagian Sarawak dan negara bagian lain kurang lebih 16.000 TKI termasuk 5.000 di antaranya sedang mendekam di penjara-penjara Malaysia. KBRI juga memprotes sikap pemerintah Malaysia yang cenderung hanya menindak TKI sedangkan majikan nakal masih belum banyak tersentuh. Misalnya baru sekitar 400 majikan yang ditindak pemerintah Malaysia jauh dari jumlah TKI yang terkena kasus. KBRI juga membantah bahwa kebijakan pemerintah Malaysia tersebut sebagai respon atas kebijakan agresif pemerintah Indonesia dalam isu penangkapan penenggelaman kapal nelayan asing termasuk dari Malaysia di kawasan perbatasan (Okezone, 8 Desember 2014).

Kasus pendeportasian TKI dari Malaysia memang menjadi isu hangat antara kedua negara selama Presiden Jokowi memimpin Indonesia. Akhir Desember 2014 di awal pemerintahan Jokowi, sebanyak 22.312 TKI dideportasi dari Malaysia (Republika, 20 Desember 2014). Sementara di Provinsi Nusa Tenggara Barat misalnya mencatat bahwa tahun 2015, ada sekitar 1.700 TKI yang dideportasi pemerintah Malaysia (Berita Satu, 12 Oktober 2015). Permasalahan pendeportasian TKI dari Malaysia juga dialami oleh provinsi seperti Kalimantan Barat. Menurut catatan BP3TKI Pontianak, sepanjang tahun 2015, pihaknya laporan sebanyak 1.904 TKI telah dideportasi oleh pemerintah Malaysia. Umumnya, kasus yang diadvokasi dari sekian banyak permasalahan TKI di Malaysia misalnya isu kematian TKI, kecelakaan kerja, depresi, pemutusan hubungan kerja (PHK) dan sakit. Selain itu, mayoritas TKI yang dideportasi merupakan TKI ilegal dengan berbagai kasus seperti izin tinggal yang telah habis, masalah dengan majikan, penunggakan gaji, masalah komunikasi, hamil di luar nikah dan meninggal dunia (RMOL, 2 Januari 2016). Sementara di Nunukan, Kalimantan Utara, juga menjadi salah satu pintu pendeportasian TKI dari Malaysia sejumlah 183 pekerja yang umumnya berstatus illegal (Kompas.com, 31 Oktober 2015). Dengan demikian tahun 2015, pemerintah Malaysia telah mendeportasi TKI leih dari 10.000 orang kembali ke Indonesia meskipun kedua negara telah mencapai beberapa kesepakatan penting terkait isu TKI. 
Tahun 2016, jumlah TKI yang dideportasi pemerintah bahkan lebih banyak lagi. Menurut catatan KJRI Johor, sepanjang tahun 2016, sebanyak 17.921 orang dengan berbagai kasus. Namun kebanyakan masih dengan isu yang lama yaitu izin tinggal (overstay) dan tidak mempunyai dokumen keimigrasian apapun. Untuk mempercepat proses pemulangan TKI ilegal, pemerintah Malaysia juga menggunakan pendekatan persuasif melalui program Program Pulang Sukarela (Voluntary Return) (Kompas.com, 18 Januari 2017). Kota Nunukan masih menjadi salah satu pintu pemulangan TKI yang sangat penting. Menurut laporan Imigrasi Nunukan dari sekian banyak TKI yang dideportasi pemerintah Malaysia, Pelabuhan Nunukan menerima sekitar 3.622 hingga September 2016. Adapun rincian dari 3.622 jumlah TKI yang dideportasi adalah seperti tabel berikut:-

Tabel 1. Deportasi TKI Melalui Pelabuhan Internasional Tunon Taka Kabupaten Nunukan

\begin{tabular}{|c|c|}
\hline Bulan & Jumlah TKI \\
\hline Januari & 282 \\
\hline Februari & 518 \\
\hline Maret & 393 \\
\hline April & 338 \\
\hline Mei & 371 \\
\hline Juni & 604 \\
\hline Juli & 450 \\
\hline Agustus & 278 \\
\hline September & 388 \\
\hline Jumlah & $\mathbf{3 . 6 2 2}$ \\
\hline
\end{tabular}

Sumber: Antara (11 Oktober 2016).

Memasuki tahun 2017, dunia ketenagakerjaan Indonesia juga dibuka dengan masalah pendeportasian TKI oleh pemerintah Malaysia. Pada awal Januari 2017, melalui negara bagian Johor pemerintah Malaysia mendeportasi sekitar 726 TKI dengan berbagai kasus. Namun, menurut KJRI Johor, kebanyakan TKI yang dipulangkan ke Indonesia merupakan residivis pasca menjalani masa hukuman di penjara di Semenanjung Malaysia hasil dari operasi penertiban oleh aparat imigrasi Malaysia (Antara, 12 Januari 2017). Satu bulan kemudian yaitu bulan Maret 2017, melalui Nunukan pemerintah Malaysia mendeportasi sekitar 375 warga negara Indonesia yang umumnya bekerja di negara bagian Sabah (Antara, 21 Maret 2017). Sementara melalui Pos Lintas Batas Negara (PLBN) Terpadu Entikong di Kabupaten Sanggau, Provinsi Kalimantan Barat, pemerintah Malaysia mendeportasi sekitar 43 TKI bermasalah yang bekerja di negara bagian Sarawak (Antara, 25 Maret 2017). Kemudian, pada bulan Mei 2017 kembali Malaysia mendeportasi sekitar 132 TKI dari Sabah melalui pintu kedatangan Nunukan, Kalimantan Utara (Kompas.com, 27 Mei 2017). Sebagaimana umumnya para TKI yang sudah bertekat berprofesi sebagai TKI, kebanyakan tetap berniat akan kembali ke Malaysia, meskipun dengan cara ilegal.

Terlepas dari berbagai masalah yang dihadapi, adalah realitas bahwa banyaknya TKI yang bekerja di Malaysia dengan segala dinamikanya telah memberikan kontribusi baik positif maupun negatif kepada negara dan diri mereka sendiri. Bagi mereka yang telah merasakan dan mendapatkan keuntungan dari bekerja di Malaysia, tentu akan memandang positif apa saja terkait kebijakan Malaysia dengan segala kekurangan dan kelebihan. Sebaliknya, bagi TKI 
yang mendapatkan pengalaman menyedihkan ketika bekerja di Malaysia, jelas akan menilai bahwa bekerja di Malaysia hanya akan membawa sengsara. Begitu juga pemerintah, disebabkan laporan yang diterima selalu berupa masalah, maka akan memberikan justifikasi bahwa bekerja di Malaysia hanya membuat masalah dan bahkan merendahkan harkat dan martabat bangsa Indonesia.

Terkait masalah pendeportasian TKI misalnya, tanggapan Presiden Jokowi cenderung negatif. Dalam sebuah laporan Presiden Jokowi menyatakan:-

"Saya memberikan target kepada Menteri Tenaga Kerja untuk membuatkan roadmap yang jelas, dan kapan kita stop yang namanya pengiriman pembantu rumah tangga (PRT)" (Kompas.com, 14 Februari 2015).

Ini artinya jelas bahwa dengan begitu banyaknya masalah yang melibatkan TKI di Malaysia khususnya pembantu rumah tangga, solusi satu-satunya menurut pemerintah adalah penghentian total pengiriman TKI sektor tersebut. Hal ini juga menunjukkan bahwa pilihan pemerintah sangat terbatas dan belum bisa menawarkan solusi lain terkait isu penanganan TKI. Rencana pemerintah tersebut juga terkesan gegabah mengingat solusi yang ditawarkan hanya untuk menuruti aspirasi pemerintah sesaat. Misalnya pemerintah merasa tersinggung dan direndahkan harga dirinya di depan Malaysia karena banyaknya warga negara Indonesia yang menjadi pembantu rumah tangga warga Malaysia. Presiden Jokowi menegaskan bahwa:-

"Di dunia hanya ada tiga negara penyuplai PRT, dua di Asia dan satu di Afrika. Yang di Asia salah satunya Indonesia. Ini masalah martabat kita. Waktu kita bilateral dengan Malaysia, satu betul-betul malu" (Kompas.com, 14 Februari 2015).

Pernyataan Presiden Jokowi jelas bahwa penghentian pengiriman TKI dilakukan untuk menaikkan harga diri Indonesia di depan Malaysia. Dalam hal ini jelas ketika para TKI berhasil memperoleh keuntungan ekonomi demi menafkahi keluarga di tengah terbatasnya lowongan pekerjaan di Indonesia sama sekali tidak menjadi ukuran. Apa yang penting Indonesia tidak malu dan rendah martabatnya di depan negara lain khususnya Malaysia, namun tidak memberikan solusi dan alternatif lebih baik daripada penghentian pengiriman TKI. Sementara dari kalangan masyarakat juga memberikan penilaian yang sama terkait isu penghentian pengiriman TKI ke Malaysia. Menurut Ketua Komisi Nasional Anti Kekerasan terhadap Perempuan (Komnas Perempuan), juga mengkritik kebijakan pemerintah yang sejak dulu terkesan reaktif dan bersifat sementara dalam setiap terjadi masalah TKI. Seharusnya menurutnya:-

"Sebuah negara baru bisa memberikan perlindungan kepada buruh migran, sepanjang negara tersebut sudah siap mempunyai perlindungan yang baik. Selain itu, negara tersebut juga harus mempunyai diplomasi yang kuat" (Kompas.com, 24 September 2010).

Kebijakan yang terkesan reaktif tersebut, justru memicu sikap defensif TKI itu sendiri yang ingin mencari solusi menurut cara mereka. Dampaknya muncul "inovasi-inovasi" baik para calo tenaga kerja maupun TKI untuk bisa lepas dari kebijakan tersebut dan bisa bekerja ke luar negeri. Berdasarkan catatan BNP2TKI, pasca rencana penghentian pengiriman TKI dan moratorium ke sejumlah negara, justru muncul modus baru sistem perdagangan manusia. Misalnya pemalsuan dokumen, melalui negara transit non-moratorium dan lain-lain (Situs Resmi BNP2TKI, 6 Januari 2015; Syamsuddin and Azlinda Azman, 2015). 
Pada waktu yang sama, Malaysia menanggapinya dengan tenang. Menurut ketua persatuan majikan pembantu rumah tangga Malaysia atau Persatuan Majikan Amah Malaysia (MAMA) Ahmad Fauzi Engku Muhsein mengatakan bahwa:-

"banyaknya negara pengirim pembantu rumah tangga tidak hanya akan memenuhi lowongan, namun juga bisa memberikan banyak pilihan kepada majikan dan bisa menghidupkan kembali industri pembantu rumah tangga [...] tanpa harus tergantung dengan satu negara tertentu" (Malaysia Kini, 16 Juli 2015).

Sementara pemerintah Malaysia menilai bahwa kehadiran pekerja asing termasuk dari Indonesia, nyata berdampak positif kepada perekonomian Malaysia. Pemerintah Malaysia juga sadar bahwa di era globalisasi yang membawa konsekuensi bebasnya arus lintas batas manusia, bisa dimanfaatkan dengan baik termasuk migrasi pekerja asing. Dengan membanjirnya pekerja asing di Malaysia, yang perlu dilakukan adalah bagaimana keberadaannya bisa bermanfaat tidak hanya kepada negara penerima, namun diharapkan juga kepada pekerja dan negara asal (Utusan Malaysia, 5 Oktober 2013). Pandangan yang sama juga diutarakan oleh beberapa akademisi Malaysia. Salah satunya menyatakan bahwa, keberadaan TKI jelas sangat penting dalam hubungan Indonesia-Malaysia. Dalam pernyataannya mengatakan:-

"bagi saya kalau diibaratkan memasak masakan yang sedap, TKI merupakan ingredient paling penting dalam masakan itu. Jadi TKI juga yang paling penting dalam hubungan Malaysia-Indonesia" (Wawancara, 14 Juni 2017).

Pernyataan di atas jelas menunjukkan bahwa posisi TKI di Malaysia memang tidak bisa dipinggirkan dalam diskursus pembangunan negara itu. Bagaimanapun, sejak awal negara Malaysia telah menggunakan jasa pekerja asing terutama dari China dan India yang kini sebagian besar sudah diakui menjadi warga negara Malaysia. Artinya, Malaysia jelas sangat diuntungkan dengan kehadiran pekerja asing termasuk dari Indonesia yang trendnya baru muncul pada tahun 1980an dan 1990an. Dalam konteks ini, tentu dinamika TKI di Malaysia juga selalu muncul dalam narasi hubungan Indonesia-Malaysia sebagai dua buah negara serumpun. Sebagai penyumbang terbesar tenaga kerja asing sektor non-formal, bisa dikatakan sebagian besar hasil pembangunan di Malaysia mulai dari kota hingga ke pelosok desa adalah karya para pencari nafkah asal Indonesia (Abubakar Eby Hara, 2008).

Dalam konteks hubungan Indonesia-Malaysia era pemerintahan Presiden Jokowi, isu TKI menimbulkan dua polemik sekaligus yaitu di kalangan TKI sendiri dan di tingkat elit antar negara Indonesia-Malaysia. Di kalangan TKI, isu TKI dihembuskan dalam rangka perlindungan warga negara Indonesia di luar negeri ketika Presiden Jokowi melakukan kampanye Calon Presiden 2014 dan pasca dilantik dalam kunjungan pertama ke Malaysia. Pada awal permulaan, harapan TKI begitu tinggi kepada pemerintah Jokowi mengingat komitmennya yang besar kepada perlindungan dan nasib TKI. Hal ini tercermin dalam berbagai pernyataan yang diwakili oleh LSM Migrant Care. Namun, dalam perjalanannya mulai muncul kekecewaan di kalangan TKI termasuk yang terdepan Migrant Care terkait kebijakan pemerintah memberhentikan pengiriman TKI ke luar negeri termasuk ke Malaysia khususnya sektor pembantu rumah tangga. Pemerintah justru dianggap tidak membela nasib TKI dan mengingkari janjinya sebagaimana masa kampanye berlangsung. Kebijakan pemerintah tersebut dinilai bukan solusi dan hanya bersifat reaktif di tengah berbagai kasus yang melibatkan TKI terus berlangsung di Malaysia. Pemerintah dinilai tidak memberikan 
solusi konkrit terutama menyangkut pembukan lapangan pekerjaan yang sangat terbatas di tengah derasnya isu membanjirnya pekerja asing asal China ke Indonesia.

Di tingkat elit antar negara Indonesia-Malaysia, isu TKI bukan barang baru. Sejak lama kedua negara selalu berhadapan dengan isu TKI yang tidak kunjung selesai. Hal inilah yang pada akhirnya memunculkan respon pemerintah untuk menghentikan pengiriman TKI sektor pembantu rumah tangga termasuk ke Malaysia. Pemerintah merasa malu dan hilang harkat serta martabatnya di depan Malaysia akibat banyaknya warga negara Indonesia yang bekerja sebagai pembantu rumah tangga dan sektor non-formal lain dengan gaji murah untuk orang Malaysia. Di sisi lain, Malaysia merasa terbantu dengan adanya pekerja Indonesia di banyak sektor di tengah keengganan warganya melakukan pekerjaan kasar tersebut. Namun, Malaysia juga mulai terusik dengan kebijakan sepihak pemerintah Indonesia melakukan penangkapan dan penenggelaman kapal nelayan Malaysia di daerah perbatasan tanpa negosiasi yang jelas dengan pemerintah Kuala Lumpur. Pemerintah Malaysia tentu juga berpikir keras untuk memutus ketergantungan pekerja Indonesia yang mahir dan bergaji murah. Sebaliknya, pemerintah Indonesia juga befikir keras untuk menghentikan pengiriman pekerja sektor rumah tangga ke Malaysia, namun juga kesulitan untuk menambah jumlah lowongan pekerjaan di tengah lesunya perekonomian dunia. Dalam waktu yang singkat adalah mustahil kedua negara akan menemukan solusinya. Malaysia masih akan kesulitan mencari pembantu murah dan bisa diterima masyarakat Muslim di luar Indonesia. Di lain pihak, Indonesia masih sulit membuka lapangan pekerjaan dalam jumlah besar dan dalam waktu yang singkat.

Jika ditelusuri lebih jauh apa yang sudah menjadi diskurusus di masyarakat tentang TKI sudah seharusnya ditinjau ulang. Objektifitas dan akal sehat harus dikedepankan demi mendapatkan informasi yang jelas dan tidak mengedepankan emosi. Misalnya berdasarkan data yang dilekuarkan KBRI Kuala Lumpur sepanjang tahun 2006-2008 jumlah kasus yang melibatkan TKI rata-rata 766 kasus dari total jumlah TKI di Malaysia sebanyak 2 juta orang TKI baik ilegal maupun legal atau hanya sekitar $0.03 \%$. Artinya bisa dibilang sisanya yang 99.97\% TKI di Malaysia relatif tidak bermasalah. Namun faktanya narasi yang dimunculkan justru yang $0.03 \%$ menjadi berita besar dan terus-menerus diputar serta disajikan ke masyarakat. Sebaliknya jarang sekali sebuah berita tentang kesuksesan TKI (99.97\%) dimunculkan media dan disebarkan ke masyarakat luas di Indonesia. Media tampaknya masih sesuai dalilnya "a bad news is a good news," serta cenderung tidak proporsional dan mengedepankan etika sehingga yang ada adalah isu TKI bermasalah di Malaysia (Bustami, et.al., 2012). Menurut Menteri Penerangan Malaysia Zainuddin Maidin:

"Selama ini media Indonesia memilih untuk tidak melaporkan kejayaan atau keberhasilan mereka di Malaysia. Sebaliknya, lebih menonjolkan berita sebilangan kecil TKI yang didera majikan, yang tidak dibayar gaji dan dihantar pulang kerana masuk ke Malaysia secara haram" (Buletin KJRI, 2007: 16).

Menurut Nasrullah Ali Fauzi, ada dua faktor penting dibalik tidak munculnya narasi keberhasilan TKI di Malaysia yang sebetulnya lebih dominan dibanding cerita-cerita pilu dan menyedihkan. Faktor pertama, media masa jelas lebih tertarik menyiarkan berita yang "laku" untuk dijual ke pasaran/pembaca misalnya kasus-kasus kejahatan, skandal seks dan sejenisnya yang melibatkan TKI. Faktor kedua, sikap "diam" TKI sendiri yang sukses dan berjaya dalam karirnya dinilai sebagai faktor penting mengapa berita itu tidak muncul. Para TKI yang sukses cenderung diam dan tidak mau mengekspos keberhasilannya ke publik karena ada dua kekhawatiran yaitu bisa menimbulkan kecemburuan antar sesama TKI dan kecemburuan 
dengan pekerja dan masyarakat lokal Malaysia (Narullah Ali Fauzi, 2009). Dengan demikian jelas tidak mudah untuk menyederhanakan persoalan TKI di Malaysia. Jumlah TKI yang sangat banyak hampir menyentuh angka $10 \%$ dari jumlah penduduk Malaysia adalah sebuah masalah tersendiri dan memerlukan penyelesaian secara komprehensif dan tidak bersifat $a d$ hoc.

\section{Kesimpulan}

Dari pembahasan di atas maka bisa disimpulkan bahwa di era pemerintahan Presiden Jokowi, isu TKI termasuk isu penting yang selalu menjadi pembahasan dan perhatian pemerintah. Di awal pemerintahan termasuk ketika kampanye Calon Presiden 2014, Presiden Jokowi sangat perhatian dengan urusan TKI dan perlindungan warga negara Indonesia di luar negeri. Namun, pada akhirnya justru timbul kekecewaan di kalangan TKI akibat rencana pemerintah menghentikan pengiriman TKI sektor rumah tangga ke luar negeri termasuk ke Malaysia tanpa solusi yang jelas. Apalagi, iklim bekerja di Indonesia masih jauh dari harapan di tengah terbatasnya lowongan pekerjaan dan derasnya isu kedatangan pekerja asing asal China ke Indonesia. Pada saat yang sama, kasus penganiayaan pekerja Indonesia di Malaysia masih terus berlangsung. Selain itu, pemerintah dengan segala pertimbangannya merasa dipermalukan dengan kondisi tersebut di depan Malaysia yang sudah melejit pembangunan ekonominya. Dalam situasi ini pemerintah terkesan belum bisa menawarkan solusinya secara bijak terkait TKI di tengah kompleksitasnya permasalahan bangsa yang dihadapi.

Oleh karena itu, bisa ditawarkan beberapa alternatif solusi untuk mengatasi masalah tersebut. Pertama, pemerintah tidak perlu gegabah dalam merespon pemerintah Malaysia terkait dengan isu yang melibatkan TKI. Karena, selama ini proses diplomasi berjalan dengan baik dan bisa dicarikan solusi sepanjang kedua negara mampu membangun komunikasi dengan baik. Kedua, pemerintah sebaiknya perlu merancang peta jalan (road map) yang jelas terkait penataan TKI dan tidak mengeluarkan pernyataan kontroversial. Bagaimanapun penghentian sepihak justru akan merugikan kedua belah pihak baik Indonesia maupun Malaysia. Bagi Indonesia, belum ada solusi jelas terkait kebijakan pasca penghentian dan ancaman bertambahnya angka pengangguran. Bagi Malaysia, akan kesulitan mencari pengganti pembantu rumah Muslim asal Indonesia dan potensi munculnya isu hubungan bilateral. Ketiga, pemerintah harus mulai berfikir keras untuk membuka lapangan pekerjaan bagi warga negara agar tidak perlu merantau jauh ke Malaysia. Sayangnya, hal ini malah diperparah dengan isu membanjirnya pekerja asing asal China yang sangat menyakitkan perasaan masyarakat di tengah tingginya angka pengangguran di Indonesia. Sehingga, jangan disalahkan jika kebijakan apapun yang dikeluarkan sepanjang tidak bisa menjamin mereka bekerja di tanah air dengan layak maka, para calon dan mantan TKI akan selalu berjuang keras kembali ke Malaysia meskipun dengan cara ilegal. Para TKI tentu sejak awal tidak ada yang berniat mau bekerja sebagai TKI dan buruh kasar, namun keadaan di Indonesia memaksa melakukan hal demikian demi menghidupi diri dan keluarganya.

\section{Daftar Pustaka}

AasFranko, K. (2007). "The securitization of migration: Whose justice and whose security?, Norwegian Research Council, draft paper. Dalam 
http://org.uib.no/imer/14Nordic/Papers\%20fra\%2014.\%20Migrasjonsforskerkonferans e/Aas.pdf (diakses 6 Juli 2017).

Abubakar Eby Hara (2008)."Hubungan Indonesia dan Malaysia: dari Saudara Serumpun ke 'Smart Partnership'?." Makalah dipresentasikan di Seminar Internasional IndonesiaMalaysia Up Date 27-29 Mei, Universitas Gadjah Mada, Yogyakarta, Indonesia.

Ahmad Naqiyuddin Bakar. (2008). Malaysian New Communication and ICT Policy: Regulatory Reform and the New Mode of Governance. Paper presented at the e-Asia International Conference, 11-13 November, Madrid.

Antara (11 Oktober 2016). "TKI ilegal masih marak, Malaysia deportasi lagi 3.622 orang via Nunukan.” Dalam http://www.antaranews.com/berita/589522/tki-ilegal-masih-marak-malaysia-deportasi-lagi3622-orang-via-nunukan (diakses 20 Juni 2017).

Antara (12 Januari 2017). "Malaysia deportasi 726 TKI bermasalah.” Dalam http://www.antaranews.com/berita/606388/malaysia-deportasi-726-tki-bermasalah (diakses 20 Juni 2017).

Antara (21 Maret 2017). “KJRI Sabah pulangkan mandiri 375 TKI.” Dalam http://www.antaranews.com/berita/619506/kji-sabah-pulangkan-mandiri-375tki?utm_source=related_news\&utm_medium=related\&utm_campaign=news (diakses $20 \mathrm{Juni}$ 2017).

Antara (25 Maret 2017). "Malaysia deportasi 43 TKI melalui Entikong." Dalam http://www.antaranews.com/berita/620266/malaysia-deportasi-43-tki-melaluientikong?utm_source=related_news\&utm_medium=related\&utm_campaign=news (diakses 20 Juni 2017).

BBC (7 April 2017). "9 Malaysians held in North Korea arrive home." Dalam http://edition.cnn.com/2017/03/30/asia/kim-jong-nam-malaysia-north-korea/index.html (diakses 17 Juni 2017).

BBC Indonesia (30 November 2014). "Jokowi hapus Kartu tenaga kerja luar negeri." Dalam http://www.bbc.com/indonesia/berita_indonesia/2014/11/141130_presiden_hapus_kart u_tenagakerja_luar_negeri (diakses 12 Juni 2017).

Berita Satu (23 Juni 2014). "Migrant Care Nyatakan Prabowo Nimbrung di "Tikungan Terakhir" Kasus TKI Wilfrida." Dalam http://www.beritasatu.com/politik/192029migrant-care-nyatakan-prabowo-nimbrung-di-tikungan-terakhir-kasus-tkiwilfrida.html (diakses 10 Juni 2017).

Berita Satu (12 Oktober 2015). "Sejak Januari, 1.700 TKI NTB Dideportasi dari Malaysia." Dalam http://www.beritasatu.com/nasional/313855-sejak-januari-1700-tki-ntbdideportasi-dari-malaysia.html (diakses 15 Juni 2017).

Buletin KJRI (2007). Edisi Januari-April.

Bustami, Reevany, Karim, Azhari, Maksum, Ali (2012). "Why are They Angry at Us: G-M-P Twin Matrixes and Indonesian-Malaysian Relations." Makalah dipresentasikan di 6th Indonesia-Malaysia Relations Conference, 10-12 July, Universitas Airlangga, Surabaya, Indonesia.

Caraka. (2012). Menggapai Peluang, Hadapi Tantangan Untuk Dubes Baru. Vol. 42, No.12

Chong, D., \& Druckman, J. N. (2007). Framing Theory. Annual Review of Political Science(10), 103-126.

Cohen, D., \& Crabtree, B. (2006). Qualitative Research Guidelines Project,” July 2006. Dalam http://www.qualres.org/HomeDisp-3831.html. 
Detik (23 April 2015). "Selain Alami Penyiksaan, TKW di Malaysia Ini Juga Dibuang Majikan ke Hutan." Dalam http://news.detik.com/berita/2895732/selainalamipenyiksaantkwdimalaysiainijugadibu angmajikankehutan (diakses 8 Juni 2017).

Detik (27 Desember 2016).“TKI Suyanti Disiksa di Malaysia, Pemerintah Layangkan Nota Protes." https://news.detik.com/berita/d3381679/tkisuyantidisiksadimalaysiapemerintahlayangk annotaprotes (diakses 8 Juni 2017).

Khairudin Harahap (6 Mei 2015). Dalam Laman Group Pusat Konsultasi TKI, https://www.facebook.com/search/str/Jika\%2Bkebijakan\%2Bini\%2Brasional\%2Bkita \%2Bdukung/keywords_posts?esd=eyJlc2lkIjoiUzpfSTE1NDcxODA1MjQ6Vks6Njg4 MTE3MDI4MDAxMjU0IiwicHNpZCI6eyIxNTQ3MTgwNTI0OjY4ODExNzAyODA wMTI1NCI6IlV6cGZTVEUxTkRjeE9EQTFNalE2VmtzNk5qZzRNVEUzTURJNE1E QXhNalUwIn0sImNyY3QiOiJ0ZXh0IiwiY3NpZCI6IjIyODViOTBkMzQyM2E2YzU 0MjY4ZDIx YTc2MThlNDk5In0\%3D (diakses 6 Juli 2017).

Kini News (24 Desember 2016). "Suyanti , TKI Asal Medan Ini Disiksa Majikannya Di Malaysia."

Dalam http://dunia.kini.co.id/2016/12/24/4206/suyantitkiasalmedaninidisiksamajikannyadimal aysia (diakses 8 Juni 2017).

Kompas.com (24 September 2010). "Penghentian Pengiriman TKI Bukan Solusi." Dalam http://bisniskeuangan.kompas.com/read/2010/09/24/1336137/Penghentian.Pengiriman.TKI.Bukan. Solusi (diakses 20 Juni 2017).

Kompas.com (25 Desember 2014). "TKW Disiksa di Malaysia, Gigi Dicabut dan Organ Vital Dirusak."

Dalam http://regional.kompas.com/read/2014/12/25/22591691/TKW.Disiksa.di.Malaysia.Gigi .Dicabut.dan.Organ.Vital.Dirusak (diakses 8 Juni 2017).

Kompas.com (31 Oktober 2015). "Malaysia Deportasi 183 TKI Melalui Nunukan." Dalam http://nasional.kompas.com/read/2015/10/31/10171421/Malaysia.Deportasi.183.TKI.Melalui.Nunu kan (diakses 20 Juni 2017).

Kompas.com (14 Februari 2015). “Jokowi Akan Stop Pengiriman TKI.” Dalam http://regional.kompas.com/read/2015/02/14/03274001/Jokowi.akan.Stop.Pengiriman.TKI (diakses 20 Juni 2017).

Kompas.com (20 Maret 2017). “Tindak Lanjuti Revisi UU Perlindungan TKI, Pemerintah Bentuk Badan Pelaksana Kebijakan.” Dalam http://nasional.kompas.com/read/2017/03/20/21284141/tindak.lanjuti.revisi.uu.perlind ungan.tki.pemerintah.bentuk.badan.pelaksana.kebijakan (diakses 12 Juni 2017).

Kompas.com (18 Januari 2017). "Malaysia Deportasi 17.921 WNI Tahun 2016.” Dalam http://nasional.kompas.com/read/2017/01/18/14211931/malaysia.deportasi.17.921.wni.tahun.2016 (diakses 20 Juni 2017).

Kompas.com (27 Mei 2017). "Malaysia Deportasi 132 TKI Ilegal, Biaya Pemulangan Dibebankan ke TKI." Dalam http://regional.kompas.com/read/2017/05/27/10063461/malaysia.deportasi.132.tki.ilegal.biaya.pem ulangan.dibebankan.ke.tki (diakses 20 Juni 2017).

Koran Sindo (5 September 2014). "3 TKI Asal Sukabumi Disekap Dalam Pabrik di Malaysia." Dalam 
https://daerah.sindonews.com/read/898500/21/3tkiasalsukabumidisekapdalampabrikdi malaysia1409887646 (diakses 8 Juni 2017).

Liow, J. C. (2004) Malaysia's Approach to Its Illegal Indonesian Migrant Labour Problem: Securitization, Politics, or Catharsis?. IDSS-FORD Workshop on Non-Traditional Security In Asia. Singapore: S. Rajaratnam School of International Studies, Nanyang Technological University.

Liow, J. C. (2005). The Politics of Indonesia-Malaysia Relations: One Kin, Two Nations London: Routledge Curzon.

Liputan 6 (24 Desember 2014) “TKI Asal Kupang Disiksa Majikan di Malaysia.” Dalam http://global.liputan6.com/read/2152093/tkiasalkupangdisiksamajikandimalaysia (diakses 8 Juni 2017).

Liputan 6 (31 Desember 2015). "1 TKW Dianiaya di Malaysia, Diduga Korban Perdagangan Orang." Dalam http://news.liputan6.com/read/2402080/1tkwdianiayadimalaysiadidugakorbanperdagan ganorang (diakses 8 Juni 2017).

Maksum, A., \& Bustami, R. (2014). The 1965 coup and reformasi 1998: two critical moments in Indonesia-Malaysia relations during and after the Cold War. SpringerPlus, 3(45). doi: 10.1186/2193-1801-3-45

Malaysia Kini (16 Juli 2015). “Bekalan amah: Beralih dari Indonesia?.” Dalam http://m.malaysiakini.com/news/305304 (diakses 20 Juni 2017).

Merdeka.com (2 Maret 2015). "Hukum mati WNI, Malaysia nyatakan perang lawan narkoba." Dalam https://www.merdeka.com/dunia/hukum-mati-wni-malaysia-nyatakan-peranglawan-narkoba.html (diakses 15 Juni 2017).

Migrant Care (2009). "Rapor Merah Pemerintahan SBY-JK, Dalam Agenda Perlindungan terhadap Buruh Migran Indonesia di Luar." Dalam http://www.migrantcare.net/mod.php?mod=publisher\&op=viewarticle\&cid=6\&artid=6 $\underline{78}$ (diakses 4 Februari 2013).

Muhammad Iqbal, \& Arifin Zainal. (2009). Tahap Kualiti Hidup Tenaga Kerja Indonesia di Malaysia dan Faktor-Faktor Psikologikal Yang Mempengaruhinya. Paper presented at the Persidangan Hubungan Malaysia-Indonesia, Fakulti Sastera dan Sains Sosial, Universiti Malaya, Kuala Lumpur, 6-8 August.

Nasir, M. (1998). Metode Penelitian. Jakarta: Ghalia Indonesia.

Nasrullah Ali Fauzi. (2009). Indonesia Dalam Pandangan Media Malaysia: Sebuah Kajian Awal. In Mohamad Redzuan Othman, Md Sidin Ahmad Ishak, Jas Laile S. Jaafar, Adrianus Meliala \& Sri Murni (Eds.), Setengah Abad Hubungan Malaysia-Indonesia (pp. 479-496). Shah Alam: Arah Publications.

Nor Azizan Idris. (2005). Hubungan Malaysia-Indonesia dan Isu Pendatang Tanpa Izin. In Sity Daud \& Zarina Othman (Eds.), Politik dan Keselamatan. Bangi: Penerbit Universiti Kebangsaan Malaysia.

Okezone (8 Desember 2014). "Malaysia Siap Deportasi 50.000 TKI." Dalam http://news.okezone.com/read/2014/12/07/337/1075886/malaysia-siap-deportasi-50-000-tki (diakses 15 Juni 2017).

Okezone (24 Desember 2016). "TKW Indonesia Disebut "Binatang" dan Disiksa di Malaysia." Dalam http://news.okezone.com/read/2016/12/24/18/1574897/tkwindonesiadisebutbinatangda ndisiksadimalaysia (diakses 8 Juni 2017). 
Okezone (16 Januari 2017). "Pukat UGM: Satgas Saber Pungli Belum Maksimal." Dalam http://news.okezone.com/read/2017/01/16/510/1592667/pukat-ugm-satgas-saberpungli-belum-maksimal (diakses 12 Juni 2017).

Okezone (27 Februari 2017). "Pasutri Malaysia Ditahan karena Diduga Aniaya TKI hingga Tewas."

Dalam http://news.okezone.com/read/2017/02/27/18/1629398/pasutrimalaysiaditahankarenadi dugaaniayatkihinggatewas (diakses 8 Juni 2017).

Okezone (1 Maret 2017). "Diduga Bunuh TKW Asal Indonesia, Suami-Istri di Malaysia Diciduk." http://news.okezone.com/read/2017/03/01/18/1630838/didugabunuhtkwasalindonesias uamiistridimalaysiadiciduk (diakses 8 Juni 2017).

Pipiet Senja (ed.). (2015). Seronok Negeri Jiran: Antologi Kisah WNI di Malaysia. Jakarta: Yayasan Budan Hadijah.

Pusat Sumber Daya Buruh Migran (2 Desember 2014).“TKI Masih Diperas karena Tak Miliki KTKLN." Dalam https://buruhmigran.or.id/2014/12/02/tki-masih-diperas-karena-takmiliki-ktkln/ (diakses 12 Juni 2017).

Republika (20 Desember 2014). “Menaker Lepas Pemulangan 383 TKI Ilegal dari Malaysia.” Dalam http://nasional.republika.co.id/berita/nasional/umum/14/12/20/ngv3gk-menaker-lepas-pemulangan383-tki-ilegal-dari-malaysia (diakses 20 Juni 2017).

RMOL (2 Januari 2016). “Malaysia Deportasi 1.904 TKI Ke Kalbar Sepanjang Tahun 2015.” Dalam www.rmol.co/read/2016/01/02/230220/Malaysia-Deportasi-1.904-TKI-Ke-Kalbar-SepanjangTahun-2015- (diakases 20 Juni 2017).

Ruenwai, N. (2006). Science and technology information in Thailand: policies, strategies and provision. PhD Thesis, Loughborough University.

Silfia Hanani. (2009). Sosio-Kultural Tenaga Kerja Indonesia di Malaysia. Paper presented at the Persidangan Hubungan Malaysia-Indonesia, Fakulti Sastera dan Sains Sosial, Universiti Malaya, Kuala Lumpur, 6-8 August.

Sinar Harapan (28 Februari 2015). “Ajeng Yulia, WNI Terpidana Kasus Narkoba Menanti Eksekusi Mati,”, dalam http://www.tribunnews.com/nasional/2015/02/28/ajeng-yuliawni-terpidana-kasus-narkoba-menanti-eksekusi-mati (diakses 15 Juni 2017);

Sinar Harapan (4 Maret 2015). "Pemerintah Upayakan Pembebasan Ajeng Yulia." Dalam http://www.sinarharapan.co/news/read/150304094/pemerintah-upayakan-pembebasanajeng-yulia-b-b- (diakses 15 Juni 2017).

Sinar Harapan (17 Maret 2015). "Pengiriman TKI ke Malaysia Sistem Satu Pintu." Dalam http://www.sinarharapan.co/news/read/150317025/pengiriman-tki-ke-malaysia-sistemsatu-pintu (diakses 15 Juni 2017).

Situs Resmi BNP2TKI (6 Januari 2015). “Kepala BNP2TKI Beberkan 4 Modus Trafficking Penempatan TKI.” Dalam http://www.bnp2tki.go.id/read/9760/Kepala-BNP2TKIBeberkan-4-Modus-Trafficking-Penempatan-TKI (diakses 20 Juni 2017).

Situs Resmi BNP2TKI (16 Januari 2015). "Sepanjang 2014 BNP2TKI Mencatat Penempatan TKI 429.872 Orang." Dalam http://www.bnp2tki.go.id/read/9800/Sepanjang2014BNP2TKIMencatatPenempatanTK I429.872Orang.html (diakses 8 Juni 2017).

Situs Resmi BNP2TKI (27 Desember 2016). "BNP2TKI: Majikan Harus Dihukum, dan TKI Suyanti Mendapatkan Keadilan.” Dalam 
http://www.bnp2tki.go.id/read/11955/BNP2TKI:MajikanHarusDihukumdanTKISuyant iMendapatkanKeadilan.html (diakses 8 Juni 2017).

Supriyadi, E. (2003). Sosialisme Islam: Pemikiran Ali Syari'ati. Yogyakarta: Pustaka Pelajar.

Syamsuddin and Azlinda Azman (2015). "Door to door cleaner": A new variant of human trafficking in domestic sector." Procedia - Social and Behavioral Sciences 172, pp. $405-410$.

Tribun Medan (22 Februari 2016). "Dituduh Mencuri, Seorang TKI Terekam Video Disiksa dan Dicambuk di Malaysia." Dalam http://medan.tribunnews.com/2016/02/22/dituduh-mencuri-seorang-tki-terekam-videodisiksa-dan-dicambuk-di-malaysia (diakses 13 Juni 2017).

Utusan Malaysia (5 Oktober 2013). "Malaysia iktiraf sumbangan pekerja asing bangunkan negara." Dalam http://ww1.utusan.com.my/utusan/Dalam_Negeri/20131005/dn_34/Malaysia-iktiraf-sumbanganpekerja-asing-bangunkan-negara (diakses 20 Juni 2017).

Utusan Malaysia (17 Februari 2017). “Siapa Siti Aisyah?.” Dalam http://www.utusan.com.my/berita/nasional/siapa-siti-aisyah-1.445666 (diakses 17 Juni 2017).

Utusan Malaysia (8 Juni 2017). "Kes pembunuhan Kim Jong-nam: 16 Jun ditetapkan untuk pengurusan kes." Dalam http://www.utusan.com.my/berita/mahkamah/kespembunuhan-kim-jong-nam-16-jun-ditetapkan-untuk-pengurusan-kes-1.490953 (diakses 17 Juni 2017).

VOA Indonesia (25 Februari, 2015). "Pemerintah akan Hentikan Pengiriman TKI Sektor Informal Secara Bertahap." Dalam https://www.voaindonesia.com/a/pemerintah-akanhentikan-pengiriman-tki-sektor-informal-secara-bertahap/2657994.html (diakses 10 Juni 2017).

Wan Abdul Rahman Wan Ab. Latif. (2012). Kes Perburuhan dan Tuduhan Politik Tidak Jejas Hubungan: Malaysia-Indon Cipta Masalah? Jurnal Pemikir, 67, 125-136.

Wan Shawaluddin Wan Hassan dan Zaini Othman (2009). "Ketidakstabilan Negara Jiran dan Kesannya kepada Keselamatan Malaysia. " Sosiohumanika 2(1), 59-74.

Wawancara (13 Juni 2017). Wawancara dengan salah seorang TKI di Malaysia.

Wawancara (14 Juni 2017). Wawancara dengan salah seorang akademisi Malaysia.

White, M. D., \& Marsh, E. E. (2006). Content analysis: a flexible methodology. Library Trend, 55(1), 22-45.

Yulyadi, L. (2009). Hubungan Dinamik Antara Indonesia dan Malaysia Pasca Merdeka: Peranan Faktor "Co-Religio" Dalam Hubungan Dua Hala. In Mohamad Redzuan Othman, Md Sidin Ahmad Ishak, Jas Laile S. Jaafar, Adrianus Meliala \& Sri Murni (Eds.), Setengah Abad Hubungan Malaysia-Indonesia (pp. 359-371). Shah Alam: Arah Publications. 